Article

\title{
The Buffer Effect of Different Wood Species and the Influence of Oak on Panel Composites Binders
}

\author{
Franco Policardi ${ }^{1,2}$ and Marion Thebault ${ }^{3, * \text { (D) }}$ \\ 1 Faculty of Electrical Engineering, University of Ljubljana, Tržaška cesta 25, 1000 Ljubljana, Slovenia; \\ franc.policardi@fe.uni-lj.si \\ 2 Raziskovalni Inštitut za nove tehnologije in energetiko (R.I.N.T.E.) d.o.o., Stritarjeva 6/a, 4000 Kranj, Slovenia \\ 3 Kompetenzzentrum Holz (Wood K Plus), Altenberger Straße 69, 4040 Linz, Austria, c/o: Wood Carinthian \\ Competence Center (W3C), Klagenfurter Straße 87-89, 9300 Sankt Veit an der Glan, Austria \\ * Correspondence: m.thebault@wood-kplus.at
}

Received: 25 May 2020; Accepted: 4 July 2020; Published: 12 July 2020

check for updates

\begin{abstract}
The buffer action of certain wood species can intensely affect the curing and hardening of some thermosetting wood adhesives. The present article presents a quantification of such buffering effects, determined under controlled conditions, in various wood species. The buffer capacity of oak has been found to be rather extreme and is likely to affect quite heavily the ability of urea-formaldehyde (UF) and melamine-urea-formaldehyde (MUF) wood panel adhesives in industrial operations. A variation of the buffer capacity of furnishes containing between $0 \%$ and $30 \%$ oak chips has been investigated. This was correlated with the internal bond (IB) strength of MUF bonded laboratory particleboards. The wood mixture buffering capacity increases with the oak content, while the panel IB strength decreases.
\end{abstract}

Keywords: wood buffer capacity; oak wood; wood panel composites; melamine-urea-formaldehyde; urea-formaldehyde; wood adhesives

\section{Introduction}

Wood-based panels and composites are used as intermediates in a wide range of industrial applications, such as, for example, furniture, construction, packaging or do it yourself (DIY) products [1]. Particleboard, medium density fiberboard (MDF), oriented strand board (OSB) and plywood are the most common products in the wood panel industry, and are produced by means of synthetic adhesives (resins). Among the wide range of adhesives used, amino resins, a combination of formaldehyde and urea, as well as melamine, are the most important ones, which include the most popular urea-formaldehyde (UF) and melamine-urea-formaldehyde (MUF) resins [2]. As a structural component, the wood-adhesive bond is influenced by a variety of factors. Besides the physical and mechanical wood species properties, their chemical composition, e.g., wood extractives, can play a role in bonding wooden surfaces [3]. Some studies showed that interactions between the physico-chemical characteristics of resins and the properties of the wood substrate strongly affect bond quality [4,5]. Effective bonding and jointing techniques are therefore required to enhance the mechanical and physical performances of such materials. The formation and strength of glued joints are influenced by numerous wood characteristics. Most of wood species are acidic [6], and this characteristic affects their wettability [5], as well as their interaction with the resin [7].

In chemistry, the definition for a $\mathrm{pH}$ buffer is "an aqueous solution consisting of a mixture of a weak acid and its conjugate base, or vice versa". In a wide variety of chemical applications, buffers are used as a mean of keeping $\mathrm{pH}$ at a nearly constant value, or to markedly minimize its variation. 
As a matter of fact, wood has a clear buffer effect and the latter strongly influences the hardening performance of water-carried wood adhesives that depend on $\mathrm{pH}$ variation $[8,9]$.

Particleboard manufacturers often use wood from different sources, e.g., sawdust from sawmills, chipped small-diameter roundwood and recovered wood $[1,10,11]$. As the site of growth and trees' vitality have a strong influence on the wood $\mathrm{pH}$ [12], these industrial resources are likely to change in $\mathrm{pH}$ and buffer capacities. For this reason, it is necessary to blend wood from different sources, and not to abruptly change the blend. To enhance the adhesion bond, one among other possible solutions is to pre-treat the wood chips and particles with either acid or base, or even with oxidant solutions such as peroxides. This enhances wood surface roughness and wettability [7], which further improves the wood-adhesive joint strength. However, this kind of pre-treatment also makes the process more complex and increases production costs.

The above used term "buffer capacity" refers to the wood's resistance to a change in $\mathrm{pH}$ [6]. When a high buffer capacity wood is used, a high amount of acid (generally a $\mathrm{H}_{2} \mathrm{SO}_{4}$ solution) or alkali (generally a $\mathrm{NaOH}$ solution) must be added to change the overall mixture $\mathrm{pH}$. It is important to mention that there is also a notable difference in $\mathrm{pH}$ and buffer capacity between the same tree wood and bark [13,14]. This observation enables one to realize that these resources should be separated and separately used in mixed panels manufacturing. More often than not, it is the buffer capacity fluctuation that causes most problems [15].

Wood species buffer capacity in wood panels production is a very difficult variable to control. The only chance to react to its changes and consequently adapt panels production and performance is through specific measurements. For instance, in order to obtain an optimum bond strength, the press time and temperature must be adjusted depending on the $\mathrm{pH}$ environment [6]. An interesting 2006 laboratory study demonstrated a strong relationship between the buffer capacity of particleboard furnish and its corresponding near-infrared (NIR) spectra via a multivariate analysis (chemometrics) [16]. In the same year, the buffer capacity of the wood resource was successfully predicted and applied using these techniques and models in an American particleboards plant.

As the rate of thermoset wood adhesives cross-linking is $\mathrm{pH}$-dependent, these adhesives are sensitive, either to the substrate $\mathrm{pH}$ variation, or to the lack of it $[17,18]$, and thus sensitive to the substrate buffer capacity [19]. Consequently, UF or MUF resins curing by a change in $\mathrm{pH}$ induction towards the acid field are badly affected by a wood species having a strong buffer capacity [20-23]. Park et al. [24] revealed that fiber acidity strongly affected the MDF panels internal bond (IB) strength with UF resin. Xing et al. [25] found a linear relationship between the gel time of UF resins and both absolute (acid buffering capacity-alkaline buffering capacity) and relative buffering capacity (acid buffering capacity/alkaline buffering capacity), as well as a linear relationship between the used species $\mathrm{pH}$ value and the UF resin gel time, which decreases as the $\mathrm{pH}$ value is decreasing. Industrial production tries to find a solution to this problem, most of the time using disproportionate amounts of acid-like hardening catalysts to succeed in hardening the resin, even vaguely, and sometimes not even properly. In this specific case, it is necessary to point out that short and long term damages can occur in the adhesive-wood joint when extreme $\mathrm{pH}$ values are reached [26-28]. Conversely, alkaline curing phenolic resins will be badly affected by most acidic woods, if, moreover, these have a strong buffer capacity. It has been demonstrated that no amount of alkali in the resin can bring it back to its optimal pH performance [28-31]. Thus, when wood buffering is a problem, it either retards or accelerate curing, so that the platen temperature in panels manufacturing process must be adapted to avoid pre-cure or over-cure.

Beside the complexity of these different assessments, the buffering capacity is highly variable among wood species [8]. Since 1973, wood species have been classified into two main groups: one having nearly no effect on the UF cure rate, and the other having some influence on the reaction [32].

The present paper starts with the buffering effect analysis of eight different wood species (three softwoods and five hardwoods) used in particleboard production, that may influence their gluing performances. Later, the higher or lower proportion of oak chips present in the wood composite 
furnish is here highlighted because of its particularly high buffer capacity. The work is specifically aimed at investigating the effect of oak chips addition on the buffering action exercised by the furnish, bonded with MUF adhesives. The gluing performances are evaluated by panels' IB measurement.

\section{Materials and Methods}

Different freshly prepared wood species particles were placed in water in a proportion by weight 1:4 wood:water. The eight wood species were for softwoods: pine (Pinus sylvestris), spruce (Picea abies) and douglas fir (Pseudotsuga menziesii), and for hardwoods: hornbeam (Carpinus betulus), European beech (Fagus sylvatica), birch (Betula alba), eucalyptus (Eucalyptus globulus) and oak (Quercus robur). Demineralized water at $\mathrm{pH} 6$ was used. The wood particles were ground to fine powders and fibers of a size ranging between 0.5 and $1 \mathrm{~mm}$, and immersed in water according to the Sanderman and Rothkman method [33]. Then, $50.0 \mathrm{~g}$ of sawdust was mixed with $200 \mathrm{~mL}$ of water, and the mixture was brought to reflux for a brief period, then cooled down to $25^{\circ} \mathrm{C}$. The wood sawdust was then left in contact with the water for $24 \mathrm{~h}$ at a temperature of $23^{\circ} \mathrm{C}$. Afterwards, the solution was titrated by a $0.05 \mathrm{~N}$ solution of $\mathrm{NaOH}$ and/or $\mathrm{H}_{2} \mathrm{SO}_{4}$. The different wood species measured buffer capacity was then expressed as $\mathrm{mEq}\left(\mathrm{H}^{+}\right)$and $\left(\mathrm{OH}^{-}\right)$to evolve the $\mathrm{pH}$ between 3 and $10 \mathrm{on} 100 \mathrm{~g}$ of dry wood. In this case, and under these conditions, the buffer capacity is calculated as:

$$
\text { Buffer capacity }=\frac{\left(v_{1}+v_{2}\right) \times 0.05 \times 200}{250}
$$

with

$v_{1}=$ volume in $\mathrm{ml}$ of $\mathrm{NaOH} 0.05 \mathrm{~N}$ added up to reach a $\mathrm{pH}$ of 10 .

$v_{2}=$ volume in $\mathrm{ml}$ of $\mathrm{H}_{2} \mathrm{SO}_{4} 0.05 \mathrm{~N}$ added up to reach a $\mathrm{pH}$ of 3 .

For each wood species and mixture, the $\mathrm{pH}$ of the solution was measured every $0.5 \mathrm{~mL}$ of $\mathrm{NaOH}$ and $\mathrm{H}_{2} \mathrm{SO}_{4}$ added solution. Each titration curve was repeated three times.

\subsection{MUF Resin Preparation}

A MUF resin with an $(\mathrm{M}+\mathrm{U}) / \mathrm{F}$ molar ratio of 1:1.2 and an $\mathrm{M} / \mathrm{U}$ weight ratio of 47:53 (where $\mathrm{M}$ is melamine, $\mathrm{U}$ is urea and $\mathrm{F}$ is formaldehyde), was prepared as follows: to 71 parts of formurea (an industrial precondensate composed of $23 \%$ urea, $23 \%$ water and $54 \%$ formaldehyde) were added to 8 parts of urea and 15 parts of water. The $\mathrm{pH}$ was adjusted at 10.2 and the temperature increased up to $92-93^{\circ} \mathrm{C}$ under continuous mechanical stirring, in reflux. As soon as the temperature was reached, the $\mathrm{pH}$ was lowered to 7.8 and the reaction continued at $92{ }^{\circ} \mathrm{C}$ for $25 \mathrm{~min}$. A $22 \% \mathrm{NaOH}$ water solution was then added to adjust the $\mathrm{pH}$ to 9.5. Then, 40 parts of melamine in 20 parts of water were added to the reaction mixture, followed by 2 parts of dimethylformamide. The temperature was maintained throughout, at $92{ }^{\circ} \mathrm{C}$ for $30 \mathrm{~min}$. The $\mathrm{pH}$ slowly dropped to $7.2-7.5$, and when the resin water tolerance reached a value of $180 \%, 21$ parts of urea premixed with 5 parts water were added, while the $\mathrm{pH}$ was raised again to 9.5. The reaction continued until the water tolerance was lower than $150 \%(\mathrm{pH}=7.7)$, and after that the $\mathrm{pH}$ was adjusted to $10.0-10.2$, by adding $22 \% \mathrm{NaOH}$ water solution. The resin was finally cooled and stored. The resulting viscosity, measured with a Brookfield RV viscometer (Brookfield Ametek, Middleboro, MA, USA), was $220 \mathrm{mPa} . \mathrm{s}$, with a solid content of $55.8 \%$. The gel time at $100{ }^{\circ} \mathrm{C}$ with $2 \mathrm{wt} \%$ ammonium sulphate $\left(\mathrm{NH}_{4}\right)_{2} \mathrm{SO}_{4}$ hardener was $95 \mathrm{~s}$.

\subsection{UF Resin Preparation}

After this, $1500 \mathrm{~g}$ of formurea (UF concentrate) composed of $47 \mathrm{wt} \%$ formaldehyde, $21 \mathrm{wt} \%$ urea and $32 \mathrm{wt} \%$ water was used. Formurea was dissolved in $90 \mathrm{~g}$ of distilled $\mathrm{H}_{2} \mathrm{O}$ in a $3 \mathrm{~L}$ round bottom flask equipped with a condenser, mechanical stirrer and thermometer. The $\mathrm{pH}$ of the solution was adjusted to $8.2-8.5$, with $30 \%$ caustic soda solution, and the temperature was raised to $65^{\circ} \mathrm{C}$. An amount of $356 \mathrm{~g}$ first urea was then charged into the solution-the temperature was increased to $88 \pm 1{ }^{\circ} \mathrm{C}$ 
and maintained for $50 \mathrm{~min}$ to carry out the hydroxymethylation reaction. Subsequently, the $\mathrm{pH}$ of the reaction mixture was adjusted to 4.8-5.0 through addition of formic acid, and the condensation reaction was continued at $90 \pm 1{ }^{\circ} \mathrm{C}$ to obtain the desired viscosity, namely above $200 \mathrm{mPa}$.s. At this point, a second amount of $588 \mathrm{~g}$ of urea was added to provide the final $\mathrm{F} / \mathrm{U}$ molar ratio wanted of 1:1.2. The resin was finally cooled up to room temperature and the $\mathrm{pH}$ set to 8.2. The viscosity of the final mixture was $212 \mathrm{mPa} . \mathrm{s}$, with a solid content of $62.3 \%$. The gel time at $100{ }^{\circ} \mathrm{C}$ with $2 \mathrm{wt} \%$ ammonium sulphate $\left(\mathrm{NH}_{4}\right)_{2} \mathrm{SO}_{4}$ hardener was $110 \mathrm{~s}$.

\subsection{Particleboard Testing}

The glue mixes were prepared by adding $3 \%$ ammonium sulphate $\left(\mathrm{NH}_{4}\right)_{2} \mathrm{SO}_{4}$ hardener on resin solids. Duplicate one-layer laboratory particleboard of $350 \times 310 \times 14 \mathrm{~mm}$ were prepared using industrial wood chips, composed of an oak and pine furnish in different proportions, as outlined in Table 1. The resin load used was $10 \%$ of total MUF solids content on dry wood. The resinated furnish mat was hot pressed for $5 \mathrm{~min}$. The cycle consisted of a $28 \mathrm{~kg} / \mathrm{cm}^{2}$ maximum pressure for $2 \mathrm{~min}$ from platen contact to high pressure (the 2 min included also the maintenance time at high pressure), followed by a descending pressing cycle of $1 \mathrm{~min}$ at $12-14 \mathrm{~kg} / \mathrm{cm}^{2}$, and ending with $2 \mathrm{~min}$ at $5-7 \mathrm{~kg} / \mathrm{cm}^{2}$, all at $190^{\circ} \mathrm{C}-195^{\circ} \mathrm{C}$. The final resinated chips moisture content was $12 \%$. After light surface sanding, the panels were tested for dry IB strength. The final value is an average of five repetitions.

Table 1. Internal bond (IB) strength of laboratory particleboard panels prepared using a melamine-urea-formaldehyde (MUF) resin on mixed wood furnish oak: pine at different ratios.

\begin{tabular}{ccc}
\hline $\begin{array}{c}\text { Wood Chips } \\
\text { Oak:Pine }\end{array}$ & $\begin{array}{c}\text { IB Strength } \\
(\mathbf{M P a})\end{array}$ & $\begin{array}{c}\text { Average Density } \\
\text { Dry }\left(\mathbf{k g} / \mathbf{m}^{3}\right)\end{array}$ \\
\hline $0: 100$ & $1.05 \pm 0.06$ & $0.710 \pm 0.0094$ \\
$10: 90$ & $0.99 \pm 0.03$ & $0.705 \pm 0.0062$ \\
$20: 80$ & $0.90 \pm 0.05$ & $0.700 \pm 0.0102$ \\
$30: 70$ & $0.72 \pm 0.06$ & $0.680 \pm 0.0058$ \\
$40: 60$ & $0.50 \pm 0.11$ & $0.670 \pm 0.0113$ \\
$50: 50$ & $0.34 \pm 0.10$ & $0.650 \pm 0.0098$ \\
\hline
\end{tabular}

\subsection{Buffer Capacity of Defibered Wood Mixtures and Glued with UF and MUF Adhesives}

Samples of wood-UF and wood-MUF glue mixes, prepared according to the method described above ( $10 \%$ of total adhesive solids content on dry wood), were dried using an oven at $103{ }^{\circ} \mathrm{C}$ and ground to fine powders of a size ranging between 0.5 and $1 \mathrm{~mm}$. The powders were then immersed in demineralized water at $\mathrm{pH} 6$ and prepared with the same method described above for wood sawdust.

For each mixture, the $\mathrm{pH}$ of the solution was measured every $0.5 \mathrm{~mL}$ of $\mathrm{NaOH}$ and $\mathrm{H}_{2} \mathrm{SO}_{4}$ added solution. Each titration curve was repeated three times.

\section{Results and Discussion}

Figure 1a shows the buffer capacity graphs for the different investigated wood species. These results are similar to those previously exhibited in the study of Johns and Niazi [8]. This graph indicates the extreme buffer effect of oak chips in the alkaline domain, compared to the small differences between the buffer effects of the other wood species. Figure $1 \mathrm{~b}$ has been drawn to better distinguish the buffer effect differences of the other examined wood species. The buffer capacity differences among the species other than oak are not great, and thus, a mix of chips and fibers of these species in different proportions will not markedly affect the performance of UF and MUF adhesives. Figure $1 \mathrm{~b}$ describes how beech, spruce and douglas fir had a more marked buffer effect than the other species on the alkaline side; on the acid side, beech definitely distinguishes itself as the most buffering, and eucalyptus as the least. It is worth noting that, in the acid domain, the buffer capacity of oak is not particularly different from that of the other wood species, and it is even less than the one of beech. 

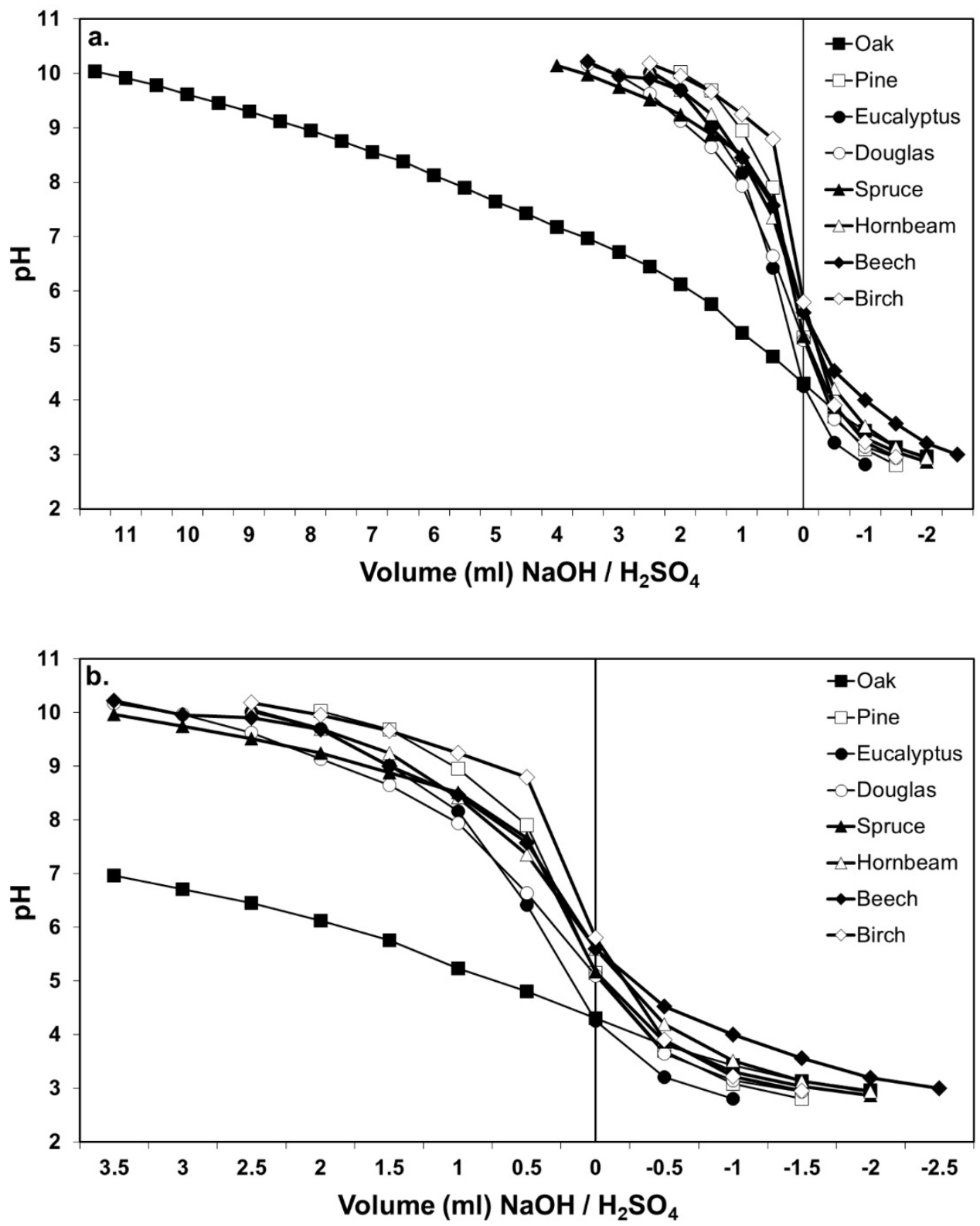

Figure 1. $\mathrm{pH}$ variation as a function of volume of $0.05 \mathrm{~N} \mathrm{NaOH}$ and/or $0.05 \mathrm{H}_{2} \mathrm{SO}_{4}$ titration solution: (a) all wood species reported; (b) expanded detail of the lower part of the curves.

As shown in Figure 1a, oak presents an extremely strong buffer capacity under alkaline conditions. The graph in Figure 2 highlights the specific oak furnish negative influence when mixed with other wood species furnish during UF and MUF bonded composite panels' manufacturing process. Here, oak chips are mixed in a $10 \%, 20 \%$ and $30 \%$ proportion, respectively, to another low buffer capacity species (pine). It also shows how, as the proportion of oak increases, so does the buffer capacity of the total furnish, when compared to the buffer capacity of the control furnish, to which no oak material has been added.

Figure 3 presents the effects of $10 \%$ oak chips presence in the panel furnish buffer action on a MUF and an UF adhesive. For such resins, and in the presence of oak chips, the $\mathrm{pH}$ decreasing to hardening levels may cause the need to increase the acid quantity. This effect is very pronounced for the MUF resin (as melamine resins present a buffering action by themselves [21,34]). It becomes evident, then, that MUF resins will need extra acids for hardening in the presence of more than $10 \%$ oak in the wood furnish. An extreme effect has sometimes been observed in the industrial production 
process: the resin hardening is literally blocked, or so seriously slowed down, that the panel mechanical strength becomes faulty.

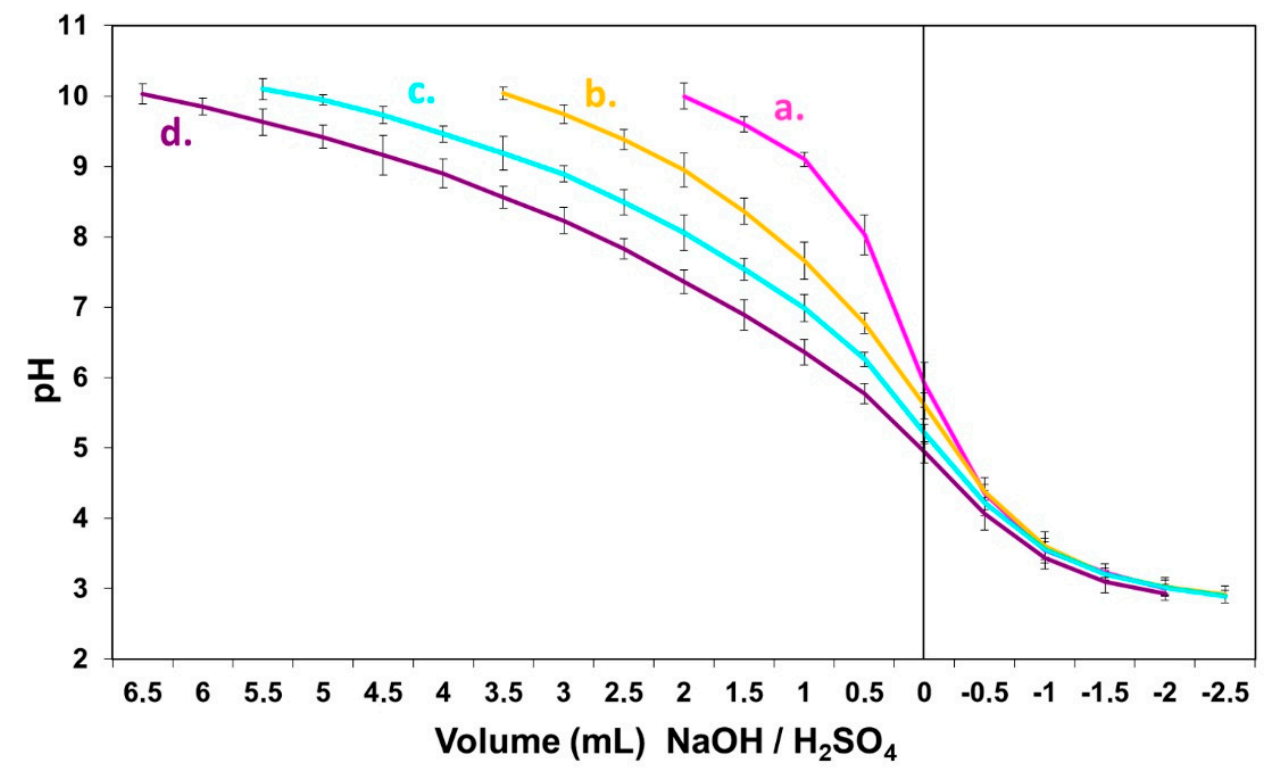

Figure 2. Buffer capacity effect of an oak/pine mixture furnish on the $\mathrm{pH}$ variation with: (a) $0 \%$ oak furnish-control; (b) 10\% oak furnish; (c) 20\% oak furnish; (d) 30\% oak furnish.

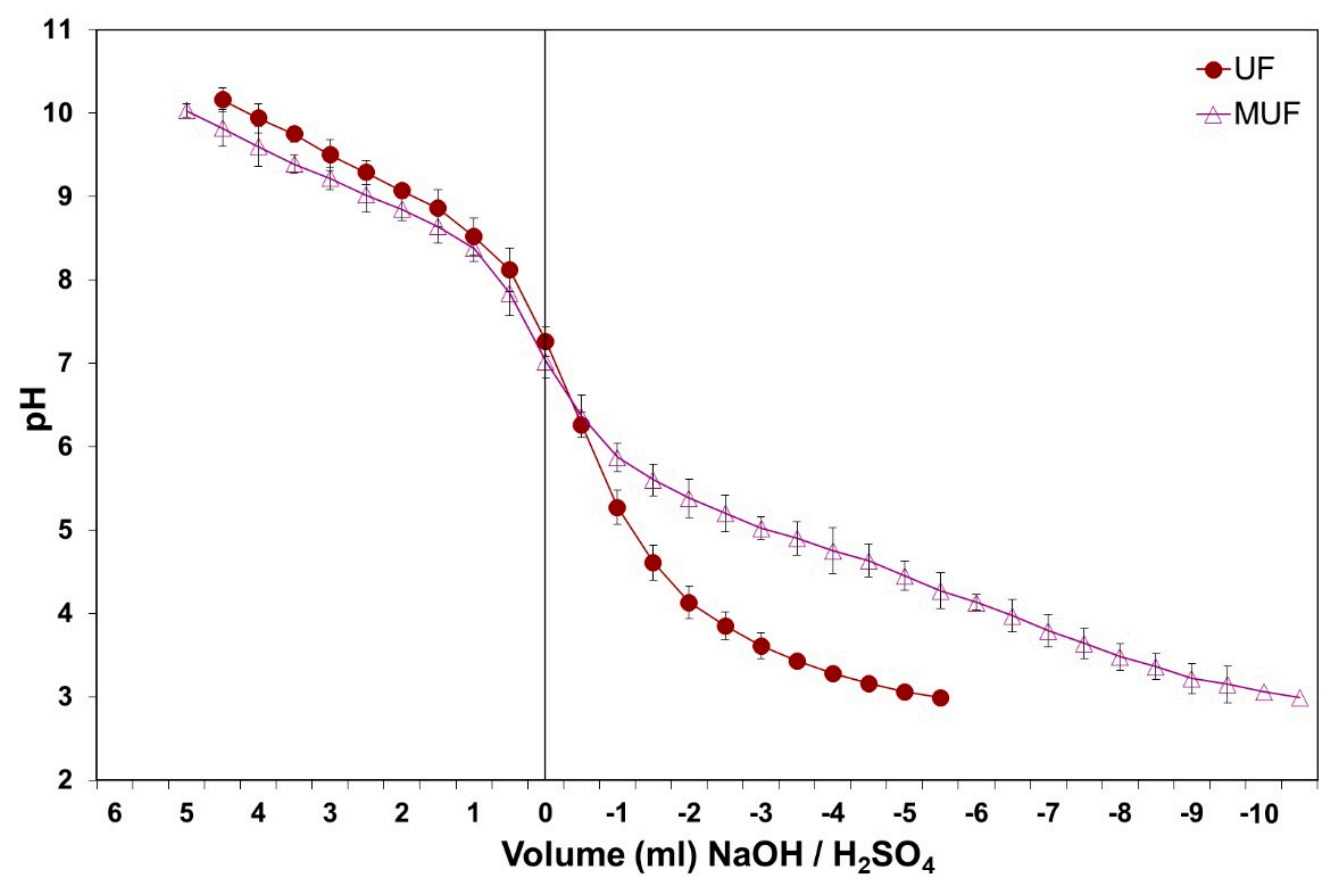

Figure 3. Adhesive type influence on the oak/pine mixture $\mathrm{pH}$ and buffer capacity, with $10 \%$ oak chips, after defibering and gluing.

The observed effect clearly appears in Figure 4, but is less damaging for UF resins; in the presence of $10 \%$ oak chips, the resin is less acidic and therefore less reactive-this is likely to also cause an adhesive hardening retardation. Meanwhile, at $10 \%$ of the oak chips, the problem appears to be easily curable for a UF resin; a higher percentage of oak chips will start to more seriously affect the UF resins hardening also. Such indications can be substantiated by laboratory particleboard testing, when the wood furnish comprises different proportions of oak chips. 


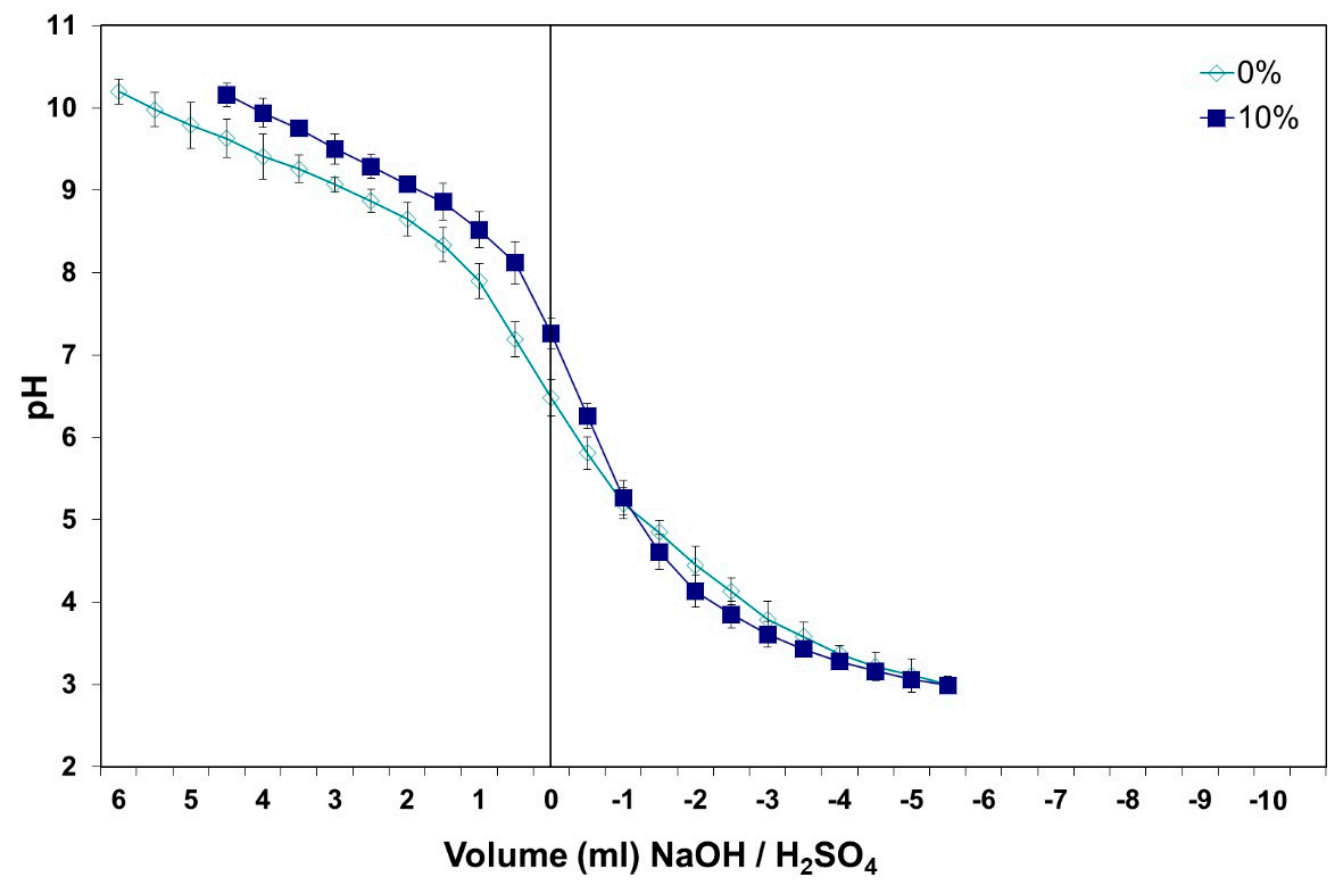

Figure 4. Oak species influence on the $\mathrm{pH}$ and buffer capacity of an oak/pine wood mixture, after defibering and gluing with a urea-formaldehyde (UF) resin.

UF and MUF adhesives generally harden by addition of an acid or acid-releasing salt, to reach a $\mathrm{pH}$ not lower than 4 [35]. Oak has a high buffer capacity maintaining the $\mathrm{pH}$ at medium levels, so curing a particleboard containing a certain proportion of oak is likely to become longer. Another study on UF demonstrated a linear relationship between the $\mathrm{pH}$ and the resin gel time [25]. The UF resin curing behavior is affected by the presence of wood raw materials in the system; this generally causes an enthalpy decrease [31]. It is then expected that the bonding quality of the particleboard is deteriorated by the presence of oak, due to an incomplete adhesive cure.

This effect can be observed from the dry IB strength of laboratory particleboard bonded with a standard MUF resin (Table 1).

The wood panel IB strength is the direct indicator of how good the bonding is. As the furnish percentage of oak chips increases, the IB strength value initially slowly decreases, then decreases progressively more and more, reaching very low values. This phenomenon attests to the negative effect of the oak buffer capacity; however, it can also be due to a difference of compressibility and surface area among pine and oak particles. Oak is denser than pine (in average 0.67 versus 0.55 with $12 \%$ moisture content [36]), and then harder to compress; some cavities between the chips can appear during the pressing stage, and weaken the gluing bond between them. Nevertheless, the whole density decreases with the oak content, with a maximal loss of only $8.5 \%$. With an oak content of $10-20 \%$ in the furnish, the decrease in IB strength is relatively low, and the density remains almost the same (within standard deviation values).

\section{Conclusions}

The buffer capacities of eight different wood species (three softwoods and five hardwoods) have been evaluated in particleboard production. A notable difference has been observed in the case of oak, in which the buffer capacity under alkaline conditions is extremely strong. The buffer capacity effect of wood mixtures has been quantified in the case of oak wood chips used in wood panel composites such as particleboards. The presence of oak chips negatively influences UF and MUF resins bonding joints, and this has repercussions on the panels' mechanical properties. While the use of up to between $10 \%$ and $20 \%$ of oak fibers and chips in the panel furnish just causes a moderate and still tolerable decrease 
in panel IB strength, the addition of higher percentages rapidly leads to a marked decrease in panel IB strength. This paper demonstrates that moderately acid-setting UF and MUF adhesives are notably and negatively influenced by such a strong oak wood furnish buffer capacity.

Author Contributions: Conceptualization, F.P. and M.T.; methodology, F.P. and M.T.; project administration, F.P.; formal analysis, F.P. and M.T.; investigation, F.P.; data curation, M.T.; visualization, M.T.; writing-original draft preparation, F.P.; writing-review and editing, F.P. All authors have read and agreed to the published version of the manuscript.

Funding: This research received no external funding.

Conflicts of Interest: The authors declare no conflict of interest.

\section{References}

1. Saravia-Cortez, A.M.; Herva, M.; García-Diéguez, C.; Roca, E. Assessing environmental sustainability of particleboard production process by ecological footprint. J. Clean. Prod. 2013, 52, 301-308. [CrossRef]

2. Gonçalves, C.; Paiva, N.T.; Ferra, J.M.; Martins, J.; Magalhães, F.; Barros-Timmons, A.; Carvalho, L. Utilization and characterization of amino resins for the production of wood-based panels with emphasis on particleboards (PB) and medium density fibreboards (MDF). A review. Holzforschung 2018, 72, 653-671. [CrossRef]

3. Bockel, S.; Mayer, I.; Konnerth, J.; Niemz, P.; Swaboda, C.; Beyer, M.; Harling, S.; Weiland, G.; Bieri, N.; Pichelin, F. Influence of wood extractives on two-component polyurethane adhesive for structural hardwood bonding. J. Adhes. 2018, 94, 829-845. [CrossRef]

4. Hse, C.-Y. Wettability of Southern Pine Veneer by Phenol Formaldehyde Wood Adhesives. For. Prod. J. 1972, 22, 51-56.

5. Mantanis, G.I.; Young, R.A. Wetting of wood. Wood Sci. Technol. 1997, 31, 339-353. [CrossRef]

6. Gadhave, R.V.; Mahanwar, P.A.; Gadekar, P.T. Factor Affecting Gel Time/Process-Ability of Urea Formaldehyde Resin Based Wood Adhesives. Open J. Polym. Chem. 2017, 7, 33-42. [CrossRef]

7. Dimitriou, A.; Hale, M.D.; Spear, M.J. The effect of $\mathrm{pH}$ on surface activation of wood polymer composites (WPCs) with hydrogen peroxide for improved adhesion. Int. J. Adhes. Adhes. 2018, 85, 44-57. [CrossRef]

8. Johns, W.E.; Niazi, K.A. Effect of $\mathrm{pH}$ and buffering capacity of wood on the relation time of urea formaldehyde resin. Wood Fiber Sci. 1980, 12, 255-263.

9. Wang, X.; Huang, Z.; Cooper, P.; Wang, X.-M.; Zhang, Y.; Casilla, R. The Ability of Wood to Buffer Highly Acidic and Alkaline Adhesives. Wood Fiber Sci. 2010, 42, 398-405.

10. Wilson, J.B. Life-cycle inventory of particleboard in terms of resources, emissions, energy and carbon. Wood Fiber Sci. 2010, 42, 90-106.

11. Parikka, M. Global biomass fuel resources. Biomass Bioenergy 2004, 27, 613-620. [CrossRef]

12. Albert, L.; Németh, Z.I.; Halász, G.; Koloszár, J.; Varga, S.; Takács, L. Radial variation of pH and buffer capacity in the red-heartwooded beech (Fagus silvatica L.) wood. Holz als Roh-und Werkst. 1999, 57, 75-76. [CrossRef]

13. Pedieu, R.; Riedl, B.; Pichette, A. Measurement of wood and bark particles acidity and their impact on the curing of urea formaldehyde resin during the hot pressing of mixed panels. Holz als Roh-und Werkst. 2008, 66, 113-117. [CrossRef]

14. Passialis, C.; Voulgaridis, E.; Adamopoulos, S.; Matsouka, M. Extractives, acidity, buffering capacity, ash and inorganic elements of black locust wood and bark of different clones and origin. Holz als Roh-und Werkst. 2008, 66, 395-400. [CrossRef]

15. Irle, M.A.; Barbu, M.C.; Reh, R.; Bergland, L.; Rowell, R.M. Wood Composites. In Handbook of Wood Chemistry and Wood Composites; Rowell, R.M., Ed.; CRC Press: Boca Raton, FL, USA, 2012; pp. 321-412.

16. Andre, N.; Young, T.M.; Rials, T.G. On-Line Monitoring of the Buffer Capacity of Particleboard Furnish by Near-Infrared Spectroscopy. Appl. Spectrosc. 2006, 60, 1204-1209. [CrossRef]

17. Blomquist, R.F.; Christiansen, A.W.; Gillespie, R.H.; Myers, G.E. Adhesive bonding of wood and other structural materials. In Clark, C. Heritage Memorial Workshop on Wood 1981: Madison, Wis.; Educational Modules for Materials Science and Engineering (EMMSE) Project Materials Research Laboratory, the Pennsylvania State University: State College, PA, USA, 1983; pp. 12-110. 
18. DeMarco, F.A.; Smith, E.A. Determination of Relative Acidity of Wood and Adhesive Joints. Ind. Eng. Chem. Anal. Ed. 1946, 18, 775-777. [CrossRef]

19. Xing, C.; Zhang, S.Y.; Deng, J.; Riedl, B.; Cloutier, A. Medium-density fiberboard performance as affected by wood fiber acidity, bulk density, and size distribution. Wood Sci. Technol. 2006, 40, 637-646. [CrossRef]

20. Maloney, T.M. Modern Particleboard and Dry-Process Fiber Board Manufacturing; Miller Freeman Publication: San Francisco, CA, USA, 1993.

21. Zanetti, M.; Pizzi, A. Upgrading of MUF polycondensation resins by buffering additives. II. Hexamine sulfate mechanisms and alternate buffers. J. Appl. Polym. Sci. 2003, 90, 215-226. [CrossRef]

22. Zanetti, M.; Pizzi, A.; Kamoun, C. Upgrading of MUF particleboard adhesives and decrease of melamine content by buffer and additives. Holz als Roh-und Werkst. 2003, 61, 55-65. [CrossRef]

23. Stefke, B.; Dunky, M. Catalytic influence of wood on the hardening behavior of formaldehyde-based resin adhesives used for wood-based panels. J. Adhes. Sci. Technol. 2006, 20, 761-785. [CrossRef]

24. Park, B.; Kim, Y.S.; Riedl, B. Effect of wood-fiber characteristics on medium density. J. Korean Wood Sci. Technol. 2001, 29, 27-35.

25. Xing, C.; Zhang, S.Y.; Deng, J. Effect of wood acidity and catalyst on UF resin gel time. Holzforschung 2004, 58, 408-412. [CrossRef]

26. Wang, X.M.; Casilla, R.; Zhang, Y.; Cooper, P.; Huang, Z.; Wang, X.A. Effect of Extreme pH on Bond Durability of Selected Structural Wood Adhesives. Wood Fiber Sci. 2016, 48, 245-259.

27. Wang, X.; Huang, Z.; Cooper, P.; Wang, X.M.; Zhang, Y.; Casilla, R. Effects of pH on lap-shear strength for aspen veneer. Wood Fiber Sci. 2013, 45, 294-302.

28. Huang, Z.; Cooper, P.; Wang, X.; Wang, X.M.; Zhang, Y.; Casilla, R. Effects of conditioning exposure on the PH distribution near adhesive-wood bond lines. Wood Fiber Sci. 2010, 42, 219-228.

29. Riedl, B.; He, G. Curing kinetics of phenol formaldehyde resin and wood-resin interactions in the presence of wood substrates. Wood Sci. Technol. 2004, 38, 69-81. [CrossRef]

30. Wang, X.; Li, Y.; Wang, S.; Yu, W.; Deng, Y. Temperature-dependent mechanical properties of wood-adhesive bondline evaluated by nanoindentation. J. Adhes. 2017, 93, 640-656. [CrossRef]

31. Xing, C.; Deng, J.; Zhang, S.Y.; Riedl, B.; Cloutier, A. Differential scanning calorimetry characterization of urea-formaldehyde resin curing behavior as affected by less desirable wood material and catalyst content. J. Appl. Polym. Sci. 2005, 98, 2027-2032. [CrossRef]

32. Gao, Z.; Wang, X.-M.; Wan, H.; Liu, Y. Curing characteristics of urea-formaldehyde resin in the presence of various amounts of wood extracts and catalysts. J. Appl. Polym. Sci. 2008, 107, 1555-1562. [CrossRef]

33. Sandermann, W.; Rothkamm, M. The determination of $\mathrm{pH}$ values of woods and their practical importance. Holz Roh Werkst. 1959, 17, 433-440. [CrossRef]

34. Kamoun, C.; Pizzi, A.; Zanetti, M. Upgrading of MUF resins by buffering additives-Part 1: Hexamine sulphate effect and its limits. J. Appl. Polym. Sci. 2003, 90, 203-214. [CrossRef]

35. Pizzi, A. Urea and melamine aminoresin adhesives. In Handbook of Addhesive Technology, 3rd ed.; Pizzi, A., Mittal, K., Eds.; CRC Press: New York, NY, USA, 2017; pp. 283-320.

36. Meier, E. The Wood Database. Available online: https://www.wood-database.com/ (accessed on 19 May 2020).

(C) 2020 by the authors. Licensee MDPI, Basel, Switzerland. This article is an open access article distributed under the terms and conditions of the Creative Commons Attribution (CC BY) license (http://creativecommons.org/licenses/by/4.0/). 